\title{
The Analysis of Tourism Development Strategy at Kampoeng Durian in the Region of Ngrogung Ngebel Ponorogo Through Nine Approach Components of Business Model Canvas
}

\author{
Dhika Amalia Kurniawan and Mohammad Zaenal Abidin
}

Department of Management, University of Darussalam Gontor, Ponorogo, East Java, Indonesia

Corresponding Author: Dhika Amalia Kurniawan dhika.amalia@unida.gontor.ac.id

Received: 30 December 2019 Accepted: 29 January 2020 Published: 6 February 2020

Publishing services provided by Knowledge E

(c) Dhika Amalia Kurniawan and Mohammad Zaenal Abidin. This article is distributed under the terms of the Creative Commons Attribution License, which permits unrestricted use and redistribution provided that the original author and source are credited.

Selection and Peer-review unde the responsibility of the 6 th ICOEN 2019 Conference Committee.

\section{S OPEN ACCESS}

\begin{abstract}
This research aims to map the excellence owned by Kampoeng Durian in Ngrogung District Ngebel that uses SWOT to analyze tourism development strategy of Kampoeng Durian Ngebel through the Business Model Canvas (BMC) approach. This research was qualitative descriptive research methods using the Business Model Canvas framework, which was used to assess several variables in the tour Kampoeng Durian Ngrogung Village. The results showed that the tourism management Kampoeng durian need to conduct various development efforts in each component Business Model Canvas. Those were building business partners with various parties (key partner), adding business activities or operations in the business of Kampoeng Durian (key activities), doing durian fruit processing into various new products/processed products (value proposition), creating a special pricing program for tourists (customer relationship), providing easy road access to the tourism site of Kampoeng Durian Strategies by adding segments that will be served in a business (segment), Other resources in providing services to tourists. (key resource), promoting in various media (channels) and adding a business income source (revenue streams).
\end{abstract}

Keywords: Business Model Canvas, Kampoeng Durian, Ngebel Ponorogo, SWOT.

\section{Introduction}

The importance of developing a tourism area becomes a task for the government and local communities. Ponorogo is famous as Reog city, whice has natural beauty and natural product results. Its natural resources have potential to be developed as a tourism object, one of them is Kampoeng Durian which is located in Ngrogung Village of Ngebel Ponorogo district. It was built 2011 with 10 hectares of land and now is in the development of 25 hectares that are currently planted 400 durian trees with 15 types among others such as Durian Pisang, Durian Kunir, Durian Bokor, Durian Sapi, and 
Durian Kanjeng, Durian Mrico, Durian Montong and other. Durian trees are planted by the farmer group "Karang Asri" with a total of approximately 200 members and it is chaired by Mr.Bambang Subagyo. According to law number 9 of 1990 it declares that tourism has are important role to be developed as land in expanding and equalizing business opportunities and employment. Furthermore, it can encaurage regional development and is capable to improve the prosperity of the community. Therefore, Kampoeng Durian as one of object tourism isproper and important to be developed as a national tourist object. In addition, a durian is king of fruit favored by the majority of people that makes this village attracts tourists from both local and foreign.

With the limited harvest time, which is once a year which occurs in December to May, it makes Kampoeng Durian tours can only operate during the durian harvest season. Because the main product that can be offered in this tour, is only tour to eat durian fruit. In this tour, there are no other products that can be offered both in terms of service, products and in terms of other tourist destinations. So this Kampoeng Durian tour in Ngrogung village will be deserted when there is no durian harvest season. In order to make the durian village as an object of tourism throughout the year with an abundant quantity of harvest, a strategy is needed in its development in various aspects both from the product aspect, service aspects and other aspects that can be enjoyed throughout the year by tourists.

In the framework of this development, complex analysis is needed both in terms of internal and external aspects, so it needs analysis SWOT (strengths, weakneses, opportunity, threat) to identify the strengths and weaknesses of Kampoeng Durian in Ngrogung Ngebel by looking at the existence of opportunities and threats. After that do advanced mapping with using 9 business components of the canvas model that consisting of nine components analysis, such as the main partners, activity, value proposition, how to engage with customers, customer segments, channels, main power source then its cost structure and flow of income. The development strategy is very important because these kampoeng is the only one kampoeng in Ponorogo who have superior natural products which is not owned by other villages in Ponorogo.

The general objectives of the research are maping the various advantages and opportunities of Kampoeng Durian Ngebel and analyzing the development strategy of Kampoeng Durian tourism through the business canvas model approach, while the specific objective of this research is helping to develop the Kampoeng Durian tourism as object that can be enjoyed throughout the year and in the future it can become a national tourism object. 


\section{Literature Review}

\subsection{Theory of Analysis SWOT}

Business is an activity carried out by an organization that provides goods or services with the aim of gaining profits [1]. Business has the potential to be able to grow and develop in the existing competition. Business can survive if it has a strategy in managing challenges in the market. Businesses need to identify in various factors into strengths and opportunities to formulate competitive strategy. One way is to use SWOT analysis such as strength, weakness, opportunity, and threats. By using SWOT analysis is expected to identify the various factors systematically by maximizing the strengths and opportunities that exist within the company and also minimize the weaknesses and threats from competitors or from the outside environment. Analysis of matrix SWOT can be used to develop strategies in four pillars, as follows: Strenge-opportunity strategy which is a strategy to maximize the internal strength which is owned by the company to reach and utilize the opportunities that exist outside the companies that can be used by companies to compete. The second is the weakness and opportunity strategy which is a strategy to minimize the weaknesses of company by taking advantage of opportunities in the market. Next is the strength-threat strategy, which is the company's strategy in reducing or minimizing the impact of external threats by maximizing existing strengths and finally the weakness-threat strategy which is a defense strategy by reducing weaknesses and avoiding external threats / existing competitors.

\subsection{Theory of Business Model Canvas}

In building a business, there are various strategies and models that can be develop to face up the existence of competitive conditions. Then, a business should have a business model in order to run plan, direct and run the objectives of the business establishment. The business model needs to be formulated to well done before a business is run. Dynamic changing times, making the model of business must be innovative so it can be survive in the middle of existing competition [2].

Business model is given opportunity to companies to make strategic option [3]. Moreover form strategic positions, develop strategies and implement changes in the company, besides, other source defines a business model as a model that illustrates how a business can be create, offer and take various values to run its operations [4]. While the business canvas model is a tool used to analyze and describe how a business 
/ business is built in a new way. Furthermore, also defines that the business model is a method used by a company to be able to survive and run its business properly [5].

In the business model there are various types of models to be able to build and develop it. One of them is using the Business Model Canvas. Furthermore,the Business Model Canvas is a tool that graphically maps key structural elements and their relationship to special positions and interconnected flows for a business [6]

There are nine elements in the business model canvas which consist of proportions of value (value proposition), (customer segment), (channel), (customer relationships), (revenue stream), (key resource),(key activity), (key partnership), and (cost structure) [7]

\subsection{Methods and Equipment}

The approach used in this study was qualitative, a research that produced descriptive data in the form of written and oral words from people and observed behavior not in the form of numbers in order to obtain data in the form of interviews, manuscripts, photographs and other official documentation [8]. Data and answers generated from these studies then be described using the 9 components Business Model Canvas.

Data collection techniques in this study used primary data obtained from the results of interviews with research informants and secondary data in the form of photos and interview records., Data collection methods used in this study were observation, interviews and documentation. The location in this study was chosen by the characteristics of the village that had superior natural results compared to other villages and had the potential to be developed so as to choose the Kampoeng Durian of Ngrogung Ngebel Ponorogo and use the subjects of the study is managers of Kampoeng Durian Ngrogung village, members of the "Karang Asri" durian farmers and also tourists.

\section{Result}

\subsection{Explanation about Strenghts, Weaknesses, Opportunities and Threats (SWOT) Kampoeng Durian Ngrogung Village, Ngebel Ponorogo}

Ngrogung Village is famous as a center for durian fruit. This place attracts tourists because it presents the main product is the durian fruit during harvest season, but when it is not the harvest season, there is no tourist in Kampoeng Durian because there is no durian that can be used as a main attraction. Kampoeng Durian Ngrogung village, of 
course has many weaknesses, strengths, opportunities and threats from various aspects in developing its object to become a tourism place of Kampoeng Durian, considering that this village has only been running for about three years.

To get information about the SWOT of Ngorogung Village as a village dubbed Kampoeng Durian, information can be obtained from various sources that are directly related and also know about Kampoeng Durian's business, such as:

\subsection{Strenghts}

In terms of Natural Resources (Durian Fruit): The variety of Durian fruits such as durian kanjeng, montong, bawor, merico, bajol and others. It has quality in terms of durian meat, taste, smell durian and color of durian. Durian that is sold at place of visit Kampoeng Durian is super (good choice). It has the results of superior durian and durian derivatives from F1 and F2 which are of much better quality. Kampoeng Durian has superior fruit, such as Durian Kanjeng which is the result of ovulation. Durian fruit can be cultivated into other types of varieties. Durian fruit can be processed into other products that can be preserved.

In terms of businesses and locations (Kampoeng Durian) (SL): The village of Ngrogung is the producer of the most durian harvests among the 8 villages in the sub-district of Ngebel, so it is agreed to become the icon of Kampoeng Durian. It is developed into a durian tourist destination in Ponorogo. It was first appeared and was known as Kampoeng Durian since the Kampoeng Durian gate was built so that it had great potential to be developed into a durian tourist destination in Ponorogo. The land in Kampoeng Durian is very wide both that has been planted with durian trees and empty land. Businesses in Kampoeng Durian can be developed in other destinations. Kampoeng Durian guarantees $100 \%$ durian to tourists. Kampoeng Durian serves consumers of durian fruit lovers. Kampoeng Durian business development is assisted by Government Agencies. Promotion comes from tourists and private institutions (by using word of mouth) through mass media etc.

In terms to human resource (Durian Farmers) (SM): The majority of Ngrogung villagers are durian farmers. Farmers have the ability and skill to maintain for durian trees to bear fruit and harvest. The farmers have a group of durian farmers in Ngrogung village. 


\subsection{Weaknesses}

In terms of natural resource (Durian Fruit) (WA): The natural characteristic of durian fruit is that it is not durable (easy to rot). The existence of durian fruit depends on the season. The quality of the durian fruit depends on the weather. Durian trees are easily exposed by pests. Durian fruit is easily attacked by fruit flies. The quality of durian fruit depends on irrigation, fertilization and maintenance. The availability of durian fruit in the Kampoeng Durian transit house is limited because only the chosen durian is sold to tourists directly, not to middlemen.

In terms of businesses and locations (Kampoeng Durian) (WL): If it is not the durian harvest season, the place of visit Kampoeng Durian is empty of visitors, there are no business operation and tourism services or other activities in tourist attractions. The infrastructure to the place of visit is not supported, the road is still narrow and difficult to access. Facilities for public are inadequate, there is no prayer room, toilet, adequate resting place and parking area. There are no directions to get to Kampoeng Durian from the main road. Kampoeng Durian tourism promotion has not been maximized. In addition Kampoeng Durian is constrained by irrigation and also the maintenance of durian trees. Labor costs are needed even though Kampoeng Durian does not operate after the durian harvest season.

In terms of human resource (Durian Farmers) (WM): The awareness of maintaining for durians with the maximum has only emerged with the existence of the Kampoeng Durian icon. Many farmers sell directly to middlemen, not entering to the place of visit in Kampoeng Durian. There are still many additional workers in treating durian who do not understand how to maintain durians here. Most of farmer groups in Kampoeng Durian have not been financially capable so they have not been able to develop many durian trees and good care. The Lack of knowledge to cultivate durian trees.

\subsection{Opportunities}

In terms of natural resource (Durian Fruit) (OA): improving the variety of durian fruits with top grafting and grafting techniques to improve the quality of durian meat. Improving the quality to derivatives of F1 and F2. Harvesting outside the durian season to provide durian fruit throughout the year. Cultivating more durian trees. Durian fruit can be varied / processed into other processed products.

In terms of business and location (Kampoeng Durian) (OL): The expansion of durian land to 15 hectares. The expansion of Kampoeng Durian tourist attractions. The addition 
of other tourist destinations to attract tourists. The addition of vehicles and public facilities to serve various tourists. Ngrogung village has natural fruits other than durian, such as mangosteen, duku, avocado, orange. Collaborating with the group of durian farmers in the district of Ngebel to help the supply of durian at Kampoeng Durian. Kampoeng Durian can do promotions in various media.

In terms of human resource (Durian Farmers) (OM): Increasing farmers' capability through training on fertilization and improving varieties. Increased awareness of farmers to cultivate durian trees. Farmers easily sell their durian fruit crops. The economy of farmers is increasing.

\subsection{Threats}

In terms of natural resource (Durian Fruit) (TA): Durian fruit trees are easily exposed by pests so they can fail crops. The quality of the durian fruit depends on the weather and season. The threat of competition from other sellers who sell durian fruit from other regions using the name of durian Ngebel. When it is not harvest season, there are durians from outside the area that are sold in the Ngebel area which can damage the image of the durian Ngebel.

In terms of businesses and locations (Kampoeng Durian) (TL): The possibility of another village in Ngebel District whice upon a tour the Kampoeng Durian icon. The possibility of new competitors or regions or districts or whice cities can emerge with the same product or the same icon.

In terms of human resource (Durian Farmers) (TM): Durian farmers in Ngrogung village have not used advanced technology to treat durian trees yet (missed technology). The capability of farmers in cultivation is still small and the process is still simple and manual.

\section{Discussion}

Based on the explanation and analysis of Kampoeng Durian's condition through nine approach Component of Business Model Canvas, conclusions can be drawn on the development of Ngrogung village Kampoeng Durian by looking at the deficiencies so that it can be formulated as follows:

1. Based on the element of Key Partner or partner of a business. The main partnerships and resources obtained from outside the company can optimize the 


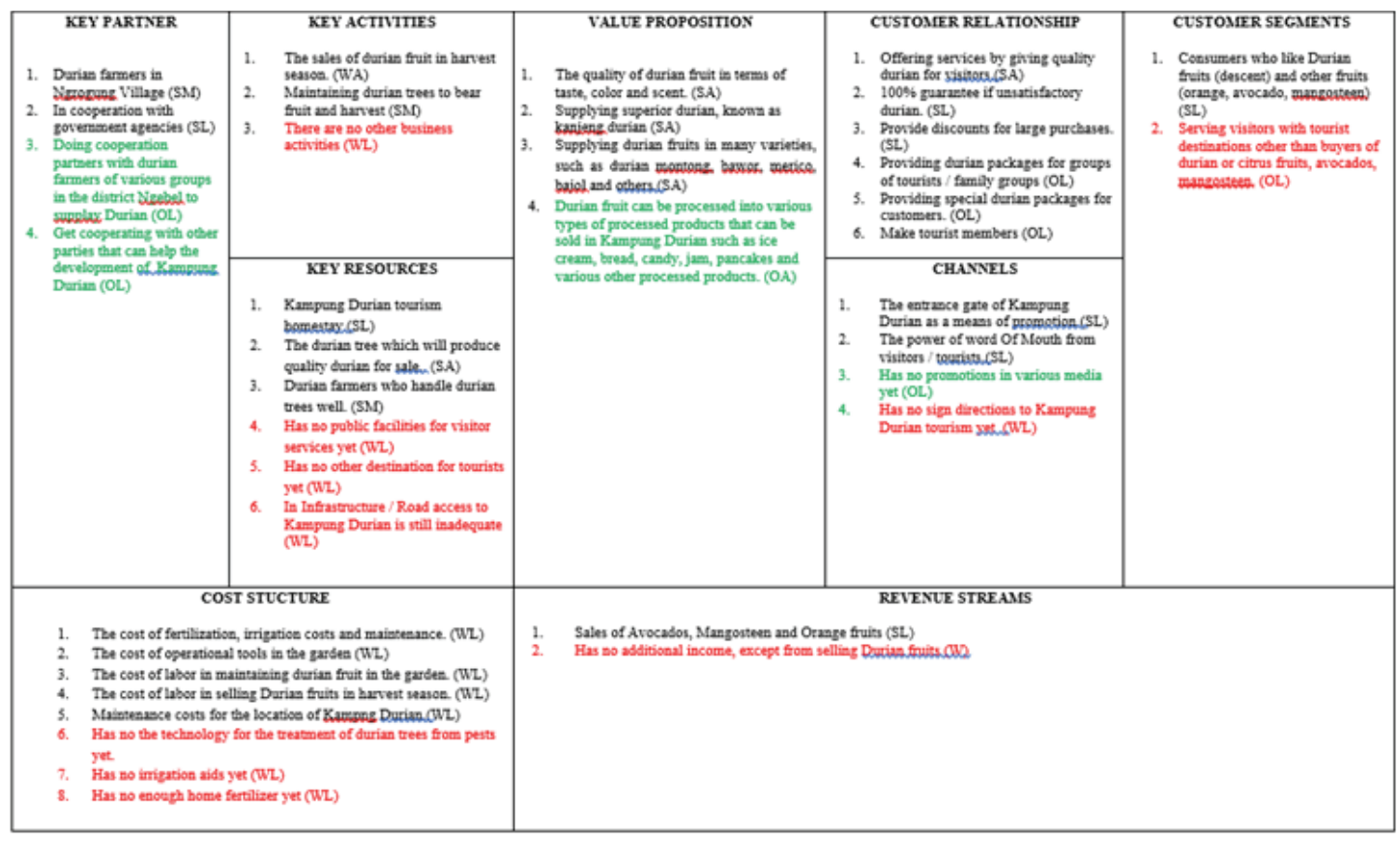

Figure 1: The Business Canvas Model at Kampoeng Durian, Ngrogung Village Ngebel Ponorogo District (Source: Ostewalder and Pigneur (2013), processed by the author. Information: Black is Business Model Canvas at Kampoeng Durian, Green is opportunities and Red is threat).

performance of a business (Ostewalder, 2013). It can be seen that the business of Kampoeng Durian is operated well by the help of the durian farmers in Ngrogung village to help producing durian fruits and supplying them to Kampoeng Durian tourism shelter, in addition to establishing business partners with government agencies such as the tourism agency and non-government agencies to get assistance both in terms of funds and promotions.

In developing Kampoeng Durian tourism in the long term, the manager can develop by establishing partnerships with various parties, both government and non-governmental parties to foster business development in Kampoeng Durian through service programs, funding programs, business development programs and other programs.

2. Based on the element of Key Activities or the main activity of a business. It can be seen that the main activity in Kampoeng Durian is selling durian fruit during the harvest season and when it is not harvest season there is no business activity in Kampoeng Durian other than maintaining for durian trees and other fruit trees.

Based on the explanation above, the tourism managers of Kampoeng Durian can develop in the form of other business activities that can revive business activities or operations in Kampoeng Durian both in the harvest season and not harvest season, so that business activities can run every time. This can be done by opening other 
tourist rides, selling other products, opening restaurants in tourist locations and so on.

3. Based on the element of Value Proposition or something offered by the business to consumers. It can be seen that the value offered to tourists is by providing the high quality of durian fruit, color and aroma, while or providing superior fruit in the Kampoeng Durian known as Durian Kanjeng, as well as various other types of durian. However, Kampoeng Durian does not have processed products from durian fruit, so it can only provide durian fruits for tourists during the harvest season.

Based on the explanation of value preposition, manager of Kampoeng Durian could develop by performing processing durian fruit into a variety of new products that can support operational activities Kampoeng Durian throughout the year, such as ice cream, bread/ cake, candy, jam, pancakes and various processed products others.

4. Based on the element of Customer Relationship or the business way in maintaining customer relationships. It can be seen that Kampoeng Durian is trying to establish relationships with consumers by providing services to tourists such as provide quality durian so that tourists are not disappointed, besides it also provides a $100 \%$ guarantee of dissatisfaction. On the other hand, Durian village manager does not have a special program for tourists.

To develop Kampoeng Durian tourism in maintaining customer relations, the manager can make a special program for tourists in the form of providing durian packages for groups of tourists or family at special prices, Providing special durian packages for customers and also making tourist members whice is useful to provide special program or promo for members. Maintaining good relations with customers through the proportion of value offered by a business is the key success of long-term business [9]

5. Based on the element of Customer Segments or segments of tourists who will visit a business. A business can choose one or more market segmentation to be served by looking at the strength of the business in pursuing the consumer market [10]. It can be seen that Kampoeng Durian has a market segment, like consumers who like Durian fruit (mainly) and other fruits (oranges, avocados, mangosteen), it is caused by the main product offered in Kampoeng Durian tourism is durian, while the others fruits are just additional products. The business in Kampoeng Durian does not have a general segment yet. 
According to this,, the tourism managers of Kampoeng Durian can develop by adding segments to be served, such as not only consumers of durian fruit enthusiasts, but other consumers or visitors with tourist destinations besides durian fruit tours. Other source also stated that a business can add new segments to be able to developed and made it as an opportunity, the segment can be educative, environmental communities, tourism communities and other segments in accordance with the value offered in business [11].

6. Based on the the element of Key Resources or in the form of physical assets owned by a business. It can be seen that the main resource possessed by Kampoeng Durian tours to operate are Kampoeng Durian, Durian trees that will produce quality durian for sale (natural resources), and Durian farmers who maintain for durian trees well (human resources) [12]. On the other hand the Kampoeng Durian business does not have other resources that can support its business operations all the time because it can only operate during the harvest season.

Based on this, the tourism managers of Kampoeng Durian can develop it by providing other resources in servicing the tourists such as add destinations tours such as selfies, outbound places, baths / swimming pools, orange / durian / avocado garden attractions, durian picking tours, in addition it also needs to provide resources in the form of public facilities [13] such as musholla, toilet, gazebo and clean water to provide services to tourists. In other side, there should be improvement in road access to Kampoeng Durian which is currently still difficult, small roads and difficult terrain. In addition, the development efforts in providing easy road access to go to the tourist sites of Kampoeng Durian, could be by road repairs and road widening so that tourists can easily go to tourist attractions. This effort can be done by cooperating with the district government or related agencies to assist in improving road access to Kampoeng Durian. Human resources are one of the factors that determine the performance of an organization or business. By using the competencies possessed, human resources can have a greater proportion of the values of a company itself.

7. Based on the element of Channel or a business information channel. It can be seen that the effort of Kampoeng Durian in reaching the potential tourists is by making the sign of the gate of entrance to the village Ngrogung that reads "TOUR de KAMPOENG DURIAN". It aims to provide information to potential tourists and the general public to travel Kampoeng Durian in the village Ngrogung Ngebel that is. Besides that, the famous Kampoeng Durian come from the word of mouth 
communication from tourists related to Kampoeng Durian tourism. However, on the other hand, Kampoeng Durian tourism has not been promoted either through print media or electronic media.

Based on the previous case,, the tourism managers of Kampoeng Durian can develop by promoting both through print media like as billboards, banners, magazines, newspapers and electronic media to make Kampoeng Durian well known better and wider to community so as to attract potential tourists to visit Kampoeng Durian. Promotional efforts, according to [14] can be carried out using promotional mix consists of advertising, sales promotion, personal selling, direct marketing, publicity and direct selling. A business can adjust the promotional needs according to how to reach consumers more broadly.

Furthermore, the Kampoeng Durian business also does not have a sign directions from the highway to Kampoeng Durian. So that, in the future the manager of Kampoeng Durian can add promotional facilities by making a signpost from the highway to get to Kampoeng Durian.

8. Based on the element of Cost Structure or business cost budget structure. Cost Structure is consists of fixed costs and variable costs that must be estimated by a business and identified the highest costs needed in the business [15]. It can be seen that in order to operate bussiness Kampoeng Durian is costly, such as to treat durian trees until harvest and can be sold in Kampoeng Durian. These costs include irrigation fertilizer, maintenance and also the labor of durian plantations. In addition, labor costs [13] in making sales in Kampoeng Durian during the harvest season and maintenance costs for Kampoeng Durian tourist sites..

However, at present,, the tourism managers of Kampoeng Durian has problems in financing sophisticated technology tools for the treatment of durian trees from the attack of pests, while also being constrained in terms of irrigation due to the minimum supply of clean water in Kampoeng Durian and the absence of diesel engines for irrigation..

Furthermore, the manager of Kampoeng Durian is constrained in terms of fertilizer houses for fertilizing the durian trees, which can only be stored near the garden and are covered by makeshift tools.

Based on the previous result, the tourism Manager of Kampoeng Durian in the care of trees and gardens is to establish a partnership model with government agencies, nongovernmental and tertiary institutions to obtain cost assistance and development funding for businesses in Kampoeng Durian. 
9. Based on the element of Revenue Streams or additional income in the business. It can be seen that the Kampoeng Durian business has additional income from selling mangosteen, avocado and orange fruits. Nevertheles the business of Kampoeng Durian has no income from other sources..

According to the previous, the tourism managers of Kampoeng Durian can develop to increase the source of income from tourists in various ways such as opening other tourist rides, selling products other than fruits, income from tourist car parking, income from restaurant at tourist sites and so on.

\section{Conclusion}

The current description of the current Kampoeng Durian tourism using business model canvas is quite enough. Based on the results analysis of potential that can be developed in the business of Kampoeng Durian based on nine components of the Business Model, it can be concluded:

The tourism Manager of Kampoeng Durian needed to make various development efforts in each component of Business Model Canvas: 1) Building business partners with various partners (key partners), 2) Increasing business or operations in the main business activitie (key actifities), 3) Processing durian fruit into new variety of products / processed products (value proposition), 4) Creating a special pricing program for tourists (customer relationship), 5) Adding segments to be served in a business (segment), 6) Adding other resources in providing services to tourists (resources key), 7) Promoting in various media (channel) and, 8) Increasing sources of business income (revenue streams).

\section{Suggestion}

From the results of the research that has been done, there are some of suggestions that can be conveyed to the tourism manager of Kampoeng Durian in Ngrogung Ngebel village, as follows:

1. Kampoeng Durian Tourism in Ngrogung Village needs to add new segments, add tourist destinations or other tourist attractions in order to be able to operate all the time, not only during harvest season, to promote various media to attract consumers in visiting durian village tours and also cooperate with various external parties both government and nongovernment agencies to support the development of durian village tourism. 


\section{References}

[1] Griffin, Ricky W; Ebert, Ronald J, 2007. Volume 1. Eighth Edition. Jakarta: Erlangga Publishers.

[2] Giesen, E.et al. 2010. When And How To Innovate Your Business Model:Journal Strategy and Leadership.38 (4)

[3] Duczkowska-Piasecka., 2013 .Business Model New Strategic Thinking. Warsaw: Difin Publishers

[4] Osterwalder, Alexander and Pigneur, Yves. 2012. Designing Business Models and Similar Strategic Objects: The Contribution of IS," Journal of the Association for Information Systems: Vol.14: Iss. 5, Article 3.

[5] Tim PPM Manajemen., 2012. Business Model Canvas. Jakarta: PPM Publishers.

[6] Coes, D. H. 2014. Critically assessing the strengths and limitations of the Business Model Canvas. Unpublished Masters Thesis. University of Twente, The Netherlands

[7] Osterwalder, Alexander and Pigneur, Yves.2010.Bussiness Model Generation: a Hand Book For Visionaries, Game Change,And Chalangers :John Wiley and Son

[8] Moleong, Lexy J. 2012. Metodologi Penelitian Kualitatif. Bandung: PT Remaja Rosdakarya Publishers.

[9] Fajar, Surya. 2016. Analisis Sembilan Komponen Model Bisnis Ekowisata Internasional di Desa Gubugklakah: Al Tijaroh. Vol 2.No.1

[10] Amalia, Dhika. Moh Zaenal. 2018. Pengantar Pemasaran Islam.(Konsep, Etika, strategi dan Implementasi): Unida Gontor Press Publishers

[11] Zulfadli, Djoko Wahjuadi. 2015. Analysis Of Business Development Strategy Kampoeng Wisata Cinangneng In The District OfBogor With Business Model Canvas Approach.Telkom University.e-Proceeding of Management: Vol 2.No.3

[12] Ratih Mukti dkk.2017. Business Model Analysis of Lokawisata Baturaden with the Business Model Canvas. Jurnal Manajemen IKM. Vol. 12, No.02

[13] Mawardi dkk. 2016. Business Model of Ecotourism at Bunaken National Marine Park with the Business Model Canvas Approach. Jurnal Manajemen IKM. Vol. 11, No.01

[14] Kotler, Philip dan Gary Armstrong. 2008. Prinsip-Prinsip Pemasaran. Edisi 13 jilid 1. Jakarta: Erlangga Publishers

[15] Andrzej Tokarski, et al. 2017.The Possibility Of Using The Business Model Canvas In The Establishment Of An Operator' S Business Plan. Torun Business Review Vol 16.No.4. 